УДК 612.014.426:613.648

\title{
INFLUENCE MECHANISM OF THE NATURAL AND TECHNOGENIC ELECTROMAGNETIC FIELDS ON LIFE SAFETY
}

\author{
M.N. Tikhonov ${ }^{1}$, V.V. Dovgusha ${ }^{2}$, L.V. Dovgusha ${ }^{3}$ \\ ${ }^{1}$ International club of scientists, Russia, 191040 St. Petersburg, Ligovsky pr., 44 \\ ${ }^{2}$ Research Institute of Industrial and Marine Medicine of the Federal Office of Biomedical and Extreme, \\ Russia, St. Petersburg, Yuri Gagarin Pr., 65 \\ ${ }^{3}$ State Budgetary Educational Institution of Higher Professional Education Northwestern State Medical \\ University named after I.I. Mechnikov, Russia, 191015 St. Petersburg, Kirochnaya, 41
}

The publication discusses the issues of medico-environmental effects of scientific and technological progress in the field of electromagnetic radiation (EMR) in three areas: man-made press EMR, electromagnetic factor in the etiology of diseases, the mechanism of the effect of electromagnetic radiation.

Key words: electromagnetic field $(E M F)$, electromagnetic environment, EMF of extremely low frequency $(E L F)$, modulated ultrahigh-frequency $(U H F)$ fields, microwave radiation, radio wave sickness, power density, protection against EMR.

The impact of electromagnetic fields on human health as an industrial and environmental factor is an important issue that remains of current interest as the progress develops

Academician

The medical and hygienic significance of natural and technology-related electromagnetic fields (EMF) attracts the attention of many researchers. The life of humans as a biological species throughout its evolution has been developing in the conditions of a natural electromagnetic background.

Electromagnetic radiation (EMR) includes radiation of any frequency scale starting from zero frequency and including electrotechnical and radiofrequency ranges, infrared radiation, visible light,
UV-band, R-rays, $\square$-. radiation and cosmic radiation (see Table 1).

According to the scientific and medical literature, EMF includes EMR in the 0 to $300 \mathrm{GHz}$ range - the so-called non-ionizing electromagnetic radiation of the electrotechnical and radiofrequency range which is the subject of our research. Natural EMF and their variants provide continuous interaction of an organism with the surrounding environment (SE), form the main biological rhythms of an organism, and contain information about the changes in the external environment.

Mikhail Nikolaevich Tikhonov - Specialist in the Interdisciplinary Expert Certification, Scientific-Technical and Control Centre of Nuclear and Radiation Safety (RESCentre) (LLC "RESCentre", St. Petersburg), Academician of the International Academy of Ecology, Man and Nature Protection Sciences (MANEB) (e-mail: dtrec@ peterlink.ru; tel. +7 (812) 233-58-06, +7 (812) 233-69-39).

Dovgusha Vitaly Vasilyevich - RANS Academician, Professor, Doctor of Medicine, Director of the Institute of Industrial and Marine Medicine, scientific consultant in CJSC “ATOM - MED CENTRE” Moscow-Saint Petersburg, Prize Winner of the Government Award in Science and Technology 2010 (e-mail: vit130144@yandex.ru; tel. +7 (812) 727-48-60).

Dovgusha Lilia Vitalyevna - Candidate of Medicine, Therapist, occupational Pathologist of the highest qualification category, Assistant of the Department of Occupational Medicine in SBEI HPE "NWSMU named after I.I. Mechnikov" (State Budgetary Educational Institution of Higher Professional Education Northwestern State Medical University named after I.I. Mechnikov, Saint-Petersburg) (e-mail: vit130144@yandex.ru; tel. 8 (812) 303-50-00). 
The Electromagnetic Spectrum

\begin{tabular}{|c|c|c|c|c|c|c|}
\hline \multicolumn{6}{|c|}{ Non-ionizing radiation } & \multirow{2}{*}{$\begin{array}{r}\begin{array}{c}\text { Ionizing } \\
\text { radiation }\end{array} \\
10^{17}-10^{21}\end{array}$} \\
\hline Frequency, Hz & $1-10^{4}$ & $10^{4}-10^{12}$ & $10^{12}-10^{14}$ & $7,5 \cdot 10^{14}$ & $10^{14}-10^{17}$ & \\
\hline Wave length & $>10 \mathrm{~km}$ & $\begin{array}{l}10 \mathrm{~km}- \\
0.1 \mathrm{~mm}\end{array}$ & $\begin{array}{c}0.78 \mu \mathrm{m}-1 \\
\mathrm{~mm}\end{array}$ & $\begin{array}{c}0.78 \mu \mathrm{m}- \\
0.38 \mu \mathrm{m}\end{array}$ & $\begin{array}{c}400 \mathrm{~nm}- \\
10 \mathrm{~nm}\end{array}$ & $\begin{array}{c}10 \mathrm{~nm}-10 \\
\mathrm{pm}\end{array}$ \\
\hline \multicolumn{2}{|c|}{$\begin{array}{l}\text { Low-frequency vibrations } \\
\text { (including EMR of power } \\
\text { current) }\end{array}$} & $\begin{array}{l}\text { Radio } \\
\text { waves }\end{array}$ & $\begin{array}{l}\text { Infrared rad- } \\
\quad \text { iation }\end{array}$ & Visible light & $\begin{array}{l}\text { Ultraviolet } \\
\text { radiation }\end{array}$ & $\begin{array}{l}\text { X-rays and } \\
\text { Gamma- } \\
\text { rays }\end{array}$ \\
\hline
\end{tabular}

A targeted use of electromagnetic (EM) energy in various industries has resulted in the fact that artificial electromagnetic field has been added to the current electric and magnetic fields of the Earth, atmospheric electricity, and radio waves of the Sun and the Galaxy. Its level significantly exceeds the strength of the natural EM background. Artificial EMF include the following: power lines, in-house electrical wiring, industrial and domestic electric plants, electric transport, $\mathrm{PC}$ and television receivers, radio transmitters and radar installations, radio and cellular telephones, microwaves and more. Multiple uses of EMR sources, introduction of new hardware that creates a powerful EMF have led to an increase in the scale and intensity of their effects on humans and the biosphere as a whole [2$4,8,12,21,22,33]$.

Suffice it to say that the energy resources of the world are doubling every 10 years, while the share of variable EMF in the power industry has increased three-fold over the same period. If 35-40

years ago the issue of bioelectromagnetic compatibility affected only the cases of occupational exposure (mainly by radar stations and electrotechnological plants), today it is reasonable to talk about the threat of exposure to man-made EM-pattern of all the population of the planet no matter the age and exposure time.

With today's level of civilization (increased introduction of EM sources into everyday life and a high biological activity of technologyrelated EMR), the EM characteristic of the surrounding environment has dramatically change in the last decade. A report by the Inter-departmental Commission of the RF Security Council on Environmental Safety № 2-2 of 20.02.1996 indicates that the impact of EMR on people and the environment is becoming extremely dangerous. The total strength of EMF at different points of the earth's surface exceeds the natural radiation background by 100-10000 times. In the last 50 years, the daily output of radio radiation has grown by more than 50 thousand times. This does not include the output of radio-location stations that belong to various military agencies. The strength of magnetic fields of industrial frequencies at the locations of air-tracks and extra-high voltage substations is by times higher as compared to the natural level of the planet's magnetic field. High levels of EMR are observed in the areas of location of radio transmission centers of low, average and high frequency. There are whole regions where the level of EMR exceeds the hygienic standards in terms of human exposure [2-4,8,10,21,22,33].

Today the Earth has large electromagnetic 'spots' created by mega-cities that have completely changes the geophysical appearance of the planet. As a result, the luminosity of the Earth in the radio range exceeds the luminosity of the Sun.

In 1926, Vladimir Vernadsky, the founder of the study of noosphere, noted that "around us, 
inside us, everywhere, in everything, there is radiation of various wave length; it is alternating, coinciding, and colliding". As a matter of fact, the frequency spectrum of acoustic vibrations and EMR is very broad and includes the waves ranging from ultralow frequency ultrasound to ultrasonics, from low frequency radio waves to ionizing radiation (see Table 1).

Large cities today create areas with a high level of technology-related electromagnetic fields that have a complex dimensional, time and frequency structure; majority of the population reside here. Electric transport contributes significantly to the development of 'electromagnetic smog'. Magnetic fields generated by electric transport have a complex frequency structure; the majority of its components have a frequency below $15 \mathrm{~Hz}$. Such fields are proved to carry a serious threat to human health [2$6,8,12]$.

There has been a lot of research on electromagnetic safety of work with video-display terminals [2]. However in recent years the level of electromagnetic radiation of PCs has been significantly decreased, so researchers have lost their interest in this topic. Non-ionizing radiation prevails in many industries; nevertheless, some researchers believe that we overestimate the significance of the level of electromagnetic fields at the workplace and underestimate its significance at home [3, 4, 35].

Cellular communications including transmitting radiotechnical stations (cell sites - CS) and mobile phones (MP) are significant sources of EMR in an urban environment.

The prevalence of electromagnetic emissions is explained by a significant growth in the number of EMR sources and its significant proximity to people which to the full extent characterizes cellular communications.

The number of cellphone users worldwide reaches 2.06 billion people, in Russia - over 115 million people.

One of the parameters of cellular communications that describes their hygienic significance as a health risk factor is the conditions of cell site locations, their amount in a service area, mobile phone characteristics, exposure factors and number of users.

In recent years, a lot of attention has been paid to hypomagnetic conditions. Isolation of man or animal from the surrounding electromagnetic background can lead to more drastic consequences than the impact of rather strong magnetic fields. In this regard, there is a curious report by Sergey Ava- kyan et al [1] on mental and physical stress that would develop during radio communication between Salut-6 space station crew and Space Operations Center exactly in the time of disappearance of geomagnetic pulsations.

The analysis of the geomagnetic background in the days of aircraft accidents over the period of 1988-1998 showed that faulty actions of the crew take place, as a rule, in the time of increased geomagnetic activity. In contrast, equipment failure is usually related with decreased magnetic activity on the day of an accident [7].

Growing electromagnetic pollution of the environment in big cities is a cause of concern among hygienists and ecologists. Significant increase in the strength of EMF should be reviewed as a one-time event in terms of evolution - a huge leap with unpredictable (for the time being) biological consequences (see Table 2). "For the time being" should be considered from two positions. Protection of the genetic code of the living beings is currently coping with the growing electromagnetic technology-related smog. In the future, such a sharp (in terms of evolution) spike in the strength of EMF may result in the biological exhaustion of the genetic code as we know it.

Ultralow frequency $(0-10 \mathrm{~Hz})$ and very low frequency $(10-1000 \mathrm{~Hz})$ electromagnetic fields are generated during the operation of electric and railway transport, power lines, substations, and cable tracks. For example, the strength of electromagnetic fields in St. Petersburg is by 100-1000 times higher as compared to the natural background typical of suburbs [16, 17].

In St. Petersburg and Leningrad Region, the following entities are exposed to electromagnetic irradiation of hygienically significant levels, according to a preliminary assessment [13]:

[] Approximately $30 \%$ of the population engaged in jobs that involve production and use of electromagnetic energy (occupational exposure);

[ Approximately $60 \%$ of the St. Petersburg population exposed to non-occupational irradiation (residing in close proximity to overhead power transmission lines as well as in houses with electric stoves, PC users, cell phone users, etc.).

Characteristics of electromagnetic irradiation of the population in St. Petersburg [13] include: 
Natural background and maximum permissible level (MPL) for the technology-related background in terms of EMF

\begin{tabular}{|c|c|c|c|c|}
\hline \multirow{2}{*}{ Indicator } & \multicolumn{2}{|l|}{ Strength of the electric component, V/m } & $\begin{array}{c}\text { Power flow den- } \\
\text { sity, }\end{array}$ \\
\cline { 2 - 5 } & $50 \mathrm{~Hz}$ & $0,03-50 \mathrm{M} \mathrm{Hz}$ & $50-300 \mathrm{M} \mathrm{Hz}$ & $0,3-300 \mathrm{GHz}$ \\
\hline $\begin{array}{c}\text { Maximum natural back- } \\
\text { ground }\end{array}$ & $10^{-5}$ & $6,1 \cdot 10^{-8}-10^{-5}$ & $6,1 \cdot 10^{-8}$ & $10^{-7}$ \\
\hline $\begin{array}{c}\text { Technology-related } \\
\text { background of EMR }\end{array}$ & $10^{3}$ & $5,7 \cdot 10^{-3}-$ & $6,3 \cdot 10^{-4}$ & $10^{-3}-0,83$ \\
\hline $\begin{array}{c}\text { Exceeded natural back- } \\
\text { ground, times }\end{array}$ & $10^{8}$ & $3 \cdot 10^{-2}$ & $10^{4}$ & $8,3-10^{4}$ \\
\hline MPL & 5000 & 500 & 80 & 1000 \\
\hline
\end{tabular}

[? Dual nature of irradiation: electromagnetic background from multiple stationary sources (integral parameter) and EMF from point sources (differential parameter):

[? High concentration of EMF sources and population per unit area which makes the analysis of electromagnetic irradiation difficult;

? High probability of continuous EMF exposure in a number of situations (24/7 and for several years in a row);

? Impact on a large number of people, including children, the elderly and the ill, including those with predisposition to cancer;

According to M.Rudakov [15], evaluation and prevention of EMR are complicated due to the following reasons:

- in the majority of cases, it is impossible to limit the emission of a contaminant into the environment;

- the replacement of this factor with a less harmful one is complicated;

- it is impossible to 'clear' the air off unwanted emissions;

- one of the characteristics of irradiation in an urban environment is its aggregate impact on the population (integral parameter) as well as individual impact from strong EMF from individual sources;

- the medico-hygienic approach aimed at limiting the EMF to the natural background level is unacceptable;

- we have here a continuous impact of the electro magnetic field (24/7, for several years in a row) on large groups of people, including children, the elderly and the ill;

- it is difficult to statistically describe the parameters of radiation coming from scattered sources that operate in various modes.

The mechanism behind the biological effect of weak electromagnetic fields of both natural and technology-related origin on living being is still unclear. Nor there is an acknowledged theory. The situation is complicated by the fact that human senses do not perceive EMF fields in their entire frequency range except for the visible range; for this reason, it is impossible to evaluate the level of hazard presented by electromagnetic irradiation without using specialized equipment. Several decades is not long enough to study the impact of artificial EMF on biological objects and humans; nevertheless, the fact that EMF bear a negative impact has been confirmed. Plants, insects, birds, fish and mammals have been noted to have a high sensitivity to electromagnetic fields [23, 24].

Scientific literature presents scientific arguments regarding the health risks presented by magnetic fields of ultralow frequencies. Some sources state that $30 \%$ of people are sensitive to man-caused magnetic fields of $0.01-2 \mathrm{~Hz}$, flux density - up to $2 \mathrm{mcTl}$ (changes in the activity of slow waves on an electroencephalogram). Today, more and more attention is paid to the effects associated with electromagnetic radiation below the thermal level $\left(10 \mathrm{MW} / \mathrm{cm}^{2}\right)$. New data has been obtained recently on high sensitivity of living organisms to weak magnetic fields [24-26]. 
In terms of environment, electromagnetic pollution should be viewed as a powerful stress factor brought into the human environment; people have not been able to adapt to this factor yet since the period of adaptation normally takes a long time, sometimes it develops over several generations. Based on the available literature, we can say that EMF have a negative impact on health and under certain conditions can serve as a background for future pathologies in people subject to chronic radiation exposure.

In humans, strong EMFs affect the immune, endocrine, and central nervous systems (CNS) that perform the alarm and regulatory functions to maintain homeostasis.

EMFs contribute to the development of ageing syndrome which takes a form of decreased capacity for work, weaker immunity, various disorders, low/high cholesterol levels, suppressed reproductive function, and age-related pathologies in early life (hypertension, cerebral atherosclerosis).

The timeline for the development of health disorders associated with EMF exposure depends on various factors: frequency range, length of exposure (length of employment), radiation localization (overall or local), EMF character (modulated, continuous, discontinuous), etc. Individual characteristics are an important factor as well. Experiments have shown that modulated EMF may cause effects that are opposite to the effects caused by non-modulated EMF. The use of a pulseoscillation EMF in the experiment generated more pronounced biological effects as compared to con- tinuous radiation. High biological activity of impulse radiation has been also evidenced by high sensitivity of the cholinergic system [2-4, 21, 22, 34].

In terms of health effects, the fact of contact with a magnetic field is more significant than the field's strength. Experiments show an increase in sensitivity to EMF of individual body systems caused by other environmental factors (physical fields, chemicals, pharmaceuticals, etc.). In such cases, even a short-term contact with EMF may result in a series of neurological consequences, psychological responses as well as severe pathological responses. Based on the theory of EMF non-thermal process (cyclotron resonance, conformational changes, etc.), other manifestations of negative health effects are possible.

Research on the effects of low-intensity microwave radiation (fields modulated in the frequency range of own biological rhythms of the bio-object) on the central nervous system is of current interest. It was determined that the threshold intensity for microwave radiation modulated in this range is significantly lower as compared to the ones typical of impulse and continuous radiation [10].

A low-energy microwave field modulated in the rhythms of own brain frequencies has a pronounced cardiotropic action.

When cerebral (nerve) tissue is affected by EMF with a frequency close to the frequency of own brain biorhythms, the biological effect intensifies (Table 3).

Harmful and hazardous frequencies (by D.S. Kontorov et al, 1993)

\begin{tabular}{|l|l|}
\hline \multicolumn{1}{|c|}{ Rrequency ratio, $\mathbf{~ H z}$} & \multicolumn{1}{c|}{ Negative effects } \\
\hline 0.02 & Increase response time to excitation \\
\hline 0.06 & Persistent mental inhibition. \\
\hline $1-3$ (delta-rhythm of the brain) & Stress. \\
\hline $5-7$ (theta-rhythm of the brain) & Mental fatigue. Stress. The negative emotional arousal. \\
\hline $8-12$ (alpha-rhythm of the brain) & It affects the reactivity and excitement until the seizure activity. \\
\hline $12-31$ (beta-rhythm of the brain) & Mental fatigue. Increased stress. \\
\hline $1000-12000$ & Reduced audioaktivnosti and auditory perception in general. \\
\hline $40-70$ & $\begin{array}{l}\text { At high field strength worsening of metabolic processes. } \\
\text { Individual physiological changes, anxiety. }\end{array}$ \\
\hline
\end{tabular}


The clinical manifestations of human exposure to microwaves of various radiation intensities (modifications with additional data B.A. Minin [10])

\begin{tabular}{|c|c|}
\hline $\begin{array}{l}\text { Intensity of the mi- } \\
\text { crowaves } \mathrm{MW} / \mathrm{cm}^{2}\end{array}$ & Negative effects \\
\hline 600 & Pain during irradiation * \\
\hline 200 & Oppression of tissue redox processes $*$ \\
\hline 100 & $\begin{array}{l}\text { Increased blood pressure followed by a decrease in the case of chronic ex- } \\
\text { posure - resistant hypotension. Bilateral cataracts. }\end{array}$ \\
\hline 40 & $\begin{array}{l}\text { Heat sensation. Vasodilation. Irradiation of } 0.5-1 \mathrm{~h} \text { increases pressure by } \\
20-30 \mathrm{~mm} \mathrm{Hg} *\end{array}$ \\
\hline 20 & Stimulation of tissue redox processes \\
\hline 10 & $\begin{array}{l}\text { Asthenia after } 15 \text { minutes of irradiation, change in the bioelectric activity } \\
\text { of the brain. }\end{array}$ \\
\hline 8 & $\begin{array}{l}\text { Undefined blood changes resulting from a total exposure time of } 150 \text { hours, } \\
\text { changes in blood clotting. }\end{array}$ \\
\hline 8 & Electrocardiographic changes, changes in the receptor apparatus. \\
\hline $4-5$ & $\begin{array}{l}\text { Change in blood pressure during multiple exposures, brief leukopenia, } \\
\text { erythropenia }\end{array}$ \\
\hline $3-4$ & $\begin{array}{l}\text { Vagotonic reaction accompanied by the symptoms of bradycardia and } \\
\text { slowing of heart conductivity }\end{array}$ \\
\hline $2-3$ & $\begin{array}{l}\text { Pronounced reduction in blood pressure, increased heart rate, fluctuations } \\
\text { in the volume of blood in the heart. }\end{array}$ \\
\hline 1 & $\begin{array}{l}\text { Low blood pressure, tendency to increased heart rate, minor blood volume } \\
\text { fluctuations in the heart. Lower IOP resulting from daily exposure for } 3.5\end{array}$ \\
\hline 0,4 & The auditory effects under exposure to pulse electromagnetic radiation \\
\hline 0,3 & $\begin{array}{l}\text { Some changes in the nervous system resulting from chronic exposure for 5- } \\
10 \text { years. }\end{array}$ \\
\hline 0,1 & Electrocardiographic changes. \\
\hline$<0,5$ & Low blood pressure resulting from chronic exposure. ${ }^{*}$ \\
\hline
\end{tabular}

* intensity values are the lowest of the ones found in literature

Below is the list of EMF-determined patterns associated with the impact of non-thermal intensity microwave fields identified by various authors:

- Affect the course of biochemical reactions of intracellular metabolism and enzymatic activity of proteins - enzymes in the brain, liver and other structures;

- Affect (directly or indirectly) the transfer of genetic information (the processes of transcription and translation);

- Affect the levels of sulfgidralnyh and other groups determined by the polarity of protein molecules;

- Affect the neurohumoral regulation, in particular, the hypothalamic-pituitary and sympathoadrenal systems;

- Change the dynamics of the immune re- 
sponse and physico-chemical properties of glia in particular its electron-optical density; ed neurons;

- Rebuild the pattern of pulse flows generat-

- Change the functional activity of receptors and various ion channels, as well as structural characteristics of the clusters and water associates in biological fluids. Gender, age and state of intoxication have a significant impact on human sensitivity to weak magnetic fields [18,34].

There are two types of microwave radiation contamination in terms of dose and nature of radiation: acute and chronic (Table 4). Acute contamination includes disorders resulting from short-term exposure to microwaves with the energy density (ED) that causes a thermogenic effect. Chrnoic contamination is the result of prolonged exposure to microwave radiation with subthermal ED.

Specific effects of EMR are explained by the non-linear nature of the field effects on microstructures. The mechanism of microwave action lies in the changes in the cell membrane permeability which causes changes in the nucleotide cyclase system function that affects the activity of redox enzymes. The products of metabolism cause humoral changes in the physiological state.

Some authors suggest that animals and humans have specific receptors that perceive EMF. We believe that water molecules in biological fluids may act in such capacity.

Natural EMFs may be related to the processes that take place on the Sun or solely on Earth. In both cases, this phenomenon must be taken into consideration during space exploration and extraterrestrial flights $[1,11]$.

An interesting fact about Earth's magnetism and gravity is that both phenomena are allpermeating physical fields - nothing on Earth or beyond it can screen their impact [11].

A. Chizhevsky's argument [23] about the special inhomogeneity of helio-geophysical effects is relevant to the earthly and space environments. For this reason, it is necessary to take into account that consistent patterns that exist on Earth may not only be expressed differently when in space, but also have an opposite sign. Consequently, such situation requires adequate measures to prevent and protect from EMF [6].

Anomalous potential gradient of a magnetic field is a factor that increases the risk of cardiovascular and immune pathologies. The nature of the impact of anomalous magnetic fields on human health greatly depends on other environ- mental factors (of toxicological and radiological nature).

Most recent scientific studies have shown that humans can interact with the resonances of Earth, noosphere, biological resonances of animals and plants, through the electromagnetic spectrum of their bodies. Through Schumann's frequency, any living being can be in resonance with the Earth. The main frequency spectrum produced by human brain lies within the range of 1 to $40 \mathrm{~Hz}$; frequencies of 8-12 Hz indicate a balanced interaction with the main resonance frequency of the Earth (Table 3). The frequency coalescence here is not coincidental; it has been achieved throughout the evolution of the living beings. For this reason, any deviation is registered subconsciously, and a living object has a functional reaction to it (for example, reaction of marine animals on the approaching storm or hurricane). We can also suggest that it is alpha-rhythm $(8-10 \mathrm{~Hz})$ which performs the function of "by-passing", protection from weak electromagnetic effects of the external environment (Table 3).

The mechanism of impact of weak EMFs on living organisms lies within quite general physical phenomena that take place in condensed environments of various natures. The amount of water in the human body ranges from $65-80 \%$. Water in a human body is a sixth sense used to perceive electromagnetic waves of any range and intensity. Water by definition is a structured liquid crystal environment. In a human body, water is most sensitive to low-frequency, low-intensity EMFs $(<4$ $\mathrm{Hz}$, by times lower as compared to the Earth's magnetic field). Here lies the danger that with the help of specially generated and targeted Schumann's frequencies one can imperceptibly influence human emotions, mood, health, and brain activity. And this is not science fiction.

In his fundamental research, V. Slesarev $[19,20]$ indicates that water can reagentlessly change its properties and functions as well as those of water-containing systems, by means of changing the acid-base, redox, and complexing properties. This results in changes in the spectral characteristics, solvent power, biological and physiological functions.

Water has a low-intensity electromagnetic field $\left(\leq 10^{-5} \mathrm{~W} / \mathrm{cm}^{2}\right)$ which is visible in a broad range of frequencies $\left(10^{14} \mathrm{~Hz}<v<10 \mathrm{~Hz}\right)$. The electromagnetic field of water is registered in the conditions of growing ice, and in liquid condition - at various ranges from $\mathrm{mm}$ to $\mathrm{km}$. 
Real biochemical and biophysical reactions including cell membranes. Water structures of an in biological structures occur with discrete poten- organism are the main source of infra-red radiation tials: $-0.40 ;-0.10 ; 0.19 ; 0.49$ и $0.78 \mathrm{~W}$ at $\mathrm{pH}=7.5$ and also a regulator of its biochemical and biophys(extreme values - potential degradation of water, ical processes.

cessation of vital processes).

When a biological object is exposed to rad-

In water, a qualitative difference between iation, electromagnetic energy is absorbed mainly magnetic density and magnetic intensity disappears. by water molecules, as a result, the following is Alternating low frequency $(0.01-0.04 \mathrm{~Hz} ; 1-7 \mathrm{~Hz}$, observed [5, 9]:

etc.) and low-intensity $\left(5-50 \mu \mathrm{W} / \mathrm{cm}^{2}\right)$ magnetic

- An increase in the kinetic energy of the field affecting water experimentally causes a num- molecules, molecular groups, selective heating of ber of changes in its physical parameters which microstructures (dielectric loss) with occurrence of maintain for 72 hours. unusual temperature gralientov;

Based on the spatial, geometrical, and qua-

- Orientation of the molecules and larger litative characteristics of water associates, they can particles along the lines of EMF, relaxation and be viewed as an active participant and catalyst of polarization of the molecules; various biochemical processes [9]. It is water associates which can lower the energy barriers for the - Induction charges in the particles;

- Rotation of dipole molecules, resonance chemical, biochemical and biophysical reactions to vibrations of molecules, ions, protein chains; take place.

- Increased permeability of cell mem-

Any electromagnetic energy and available branes, ionic change in diameter (membrane chanfrequency information are addressed to specific nels), disruption of ionic currents $(\mathrm{Ca}+2, \mathrm{~K}+$, water, neuronal, protein and associated structures of etc.), A change in cell membrane potential) a living organism - twins of this information.

- Changes in the dielectric properties of the

In the last 10-15 years, the intensity of all tissues - in low frequency ranges - induced elecSchumann's resonances (waves) has been growing, trical charges on the subcellular and larger strucso humans naturally perceive EMF in the range of tures and the distribution of the induced charge on 4-7 $\mathrm{Hz}$ and 13-40 Hz. Schumann's lower frequen- the surface of the body (the change in density incy, $7.83 \mathrm{~Hz}$, is changing and approaching $8 \mathrm{~Hz}$ and duced current).

sometimes higher. The second and third Schumann's resonances are also fluctuating between 0.3 and $0.8 \mathrm{~Hz}$ respectively.

Oscillating processes in biostructures trig-

ef of the biological effects of weak EMFs of any na- changes in the molecular structures responsible for ture on living organisms, there are debatable state- the non-specificity of proteins and enzymes, conments and episodes of rush around avian influenza, formational changes in the membrane protein, aspecific pneumonia, unexplainable emergence of changes in the exchange rhythms in the water phase new virus-like diseases and emerging activity of and, eventually, non-thermal protein denaturation, neutral biological structures. We believe that pro- tissue function abnormality, increased concentragressing industry-related magnetic background, tions in metabolism products, cell damage, local changes in the frequency responses of Schumann's arousal of receptor formations and development of resonances, closed test-runs of various devices that reflex biological responses in an organism.

generate low frequency electromagnetic waves can be the cause of sudden epidemics.

In general, a pathophysiological process coveries, we can outline some features to prove the cal pathophysiological pattern: stimulation, inhibiabove statement.

Oscillating processes in biological struc- depletion. The pattern of orgaismic responses to the tures are significantly affected by EMFs. A re- EMI effect is similar to those of other stimuli in sponse to external impact is a structural change in terms of phase-based processes, nonlinearity of resthe body of humans and animals of individual water ponses, reversible changes, accumulation of biologmolecules as well as bound water, clusters and wa- ical effects dependent on the intensity and duration ter associates which structurally repeat the shapes of exposure, the initial state of the body.

of submolecular, molecular and cellular structures 
The change in the most sensitive structures turn into energy and back. It was N.I. Pirogov who of the nervous system is an early response to low- wrote about the uity of "power and substance" in intensity EMR. Morphological changes resulting the "Diary of an Old Doctor" [SPb.; Addendum to from short-term irradiation are reversible; as for the digest "Russkaya Starina", 1884. - 464 p.]. long-term irradiation, the changes are an expression From looking at more recent studies about the miof protective-adaptive processes (degenerative crocosm and electrodynamics, it becomes clear varchanges in parenchymal organs and the seminifer- ious microelectric fields in a body (electric fields ous tubules, proliferative response reticuloendo- with a "micro" prefix, but at the micro-level their thelial elements of the liver and brain microglia). value is sufficient) create a transition of singular The most drastic changes are registered in interne- fundamental particles (either electrons or other light uronic bonds of the cortex axosomatic synapse and fundamental particles) into energy; these small sensitive fibrils of the paratopic areas of the skin energy portions are enough for the functioning of and internal organs. various human organs.

Low-intensity EMR triggers fugitive func-

Speaking of heart, academician E.I. Chasov tional changes. Here, the systems which are more said that this organ is virtually an electric motor sensitive to EMR (central nervous system, endo- itself; there are enough points on the heart's surface crine system) are the first to respond to the impact; with different electric potential, and different parts less sensitive systems have a delayed response. In- of a heart have electrical currents. By having said dividual sensitivity is also important; it determines this, E.I. Chasov implicitly raised a number of the response rate which in its turn distinguishes a questions to the scientists. It seems that individual physiological response from a pathological one. fundamental particles also transition into energy EMR can have an "informative" effect, especially inside the heart and thus feed this important organ in the conditions of a significant health disorder in accordance with the general law of the energy (diseases, overwork, and harmful interference of appropriateness of diet.

other factors). The effect of the radiation shows,

At the molecular level (of a living organfirst of all, in the low-term processes (advanced ism), only very small affecting impulses are needed extremely high frequency therapy is based on this). (several photons are enough) which have a signifi-

Under EMR, the biological effects (syner- cant impact on thin biological structures, whose getics) of the structured molecules of biological angular variations have significant functional confluids have particular properties. There is a large sequences. This data corresponds with the term amount of harmless bacteria and virus-like protein "structural stability" suggested by I.R. Prigozhin in molecules in an organism. Due to the above effects, his book "From Existing to Emerging" ]27]; here they transition from a harmless state into the state this term is discussed in the context of development of pathogenic etiological agents. A modified struc- of certain situations after the impact of fluctuations tured background of the biological fluids plays an on the system - the so-called "order through fluctuimportant role here, too. Our preliminary studies ation". The main approaches to this topic are outshow that as little as $1 \mathrm{ml}$ of the physiological solu- lined in the book by I. Prigozhin co-authored by G. tion structured by a low-frequency generator and Nicolas "Self-Organization in Nonequilibrium Sysadministered abdominally $(0.5 \mathrm{ml})$ to mice or intra- tems: From Dissipative Structures to Order venously to humans can both activate physiological Through Fluctuations" [28]. The models "order processes in an organism and have a static or lytic through fluctuations" are unveiling a nonequiliimpact on hepatitis $\mathrm{C}$ virus. brium world where small causes lead to major con-

Yet a single rearrangement of the hydrogen sequences. The reason for the magnification of molecule or changes in the structural order of the of small events is quite a legitimate subject of rational the active site molecule can impact the pathogenic analysis. Same non-linearities can make order out power of bacteria, viruses, and harmless protein of the chaos of fundamental processes, and under molecules due to the changes in the protein space other circumstance bring about the results of the structure. same order and, eventually, a new coherence (oscilFrom physics we know that substance can lating or wave processes, coordinated in time, with

State Budgetary Educational Institution of Higher Professional Education Northwestern State Medical University named after I.I. Mechnikov, Russia, 191015 St. Petersburg, Kirochnaya, 41 
a constant phase differential) laying beyond a dif- nection of fractal resonators; they also maintain the ferent bifurcation. The achievements of biological coherence of the biological system at each of the synergetics of non-linear non-equilibrium dynamic hierarchical levels. Only because of biological fluopen systems clearly explain the mechanism behind ids, all the thin structures respond to external expothe effect of weak and superweak physical fields on sure, including EMR, in the same way. Small-scale biological structures of an organism [29-32]. Every interaction in the system can have both positive and biological and biochemical structure in a living or- negative effects.

ganism has its own spatial position of a molecule.

Serving as the fundamental receptor of all Structural changes in water molecules in an organ- the electromagnetic effects, in our opinion, strucism can change the angular orientation and the di- tural formations of biological fluids are the first rection of rotation of one biological molecule atom link on low and super-low effects both inside an against the other, one molecular group against the organism and in sensitivity to (perception of) exterother. The chemical composition in this case is con- nal irradiation. Water in a living organism defines stant, chirality does not change - the spatial struc- the biological compatibility of molecular compoture changes and, respectively, biological effects nents and metabolic variability. The functions of emerge. For example, xenon clusters or post-xenon liver, kidney and other systems depend on the conwater associates in biological fluids. Chromosome dition of the biological fluids, redox and metabolic chain breakages take place under non-thermal radi- processes (living - dead water [9[).

ation of different nature - it is the level of interac- The change in the internal control impulses tion between a biological structure and a biological of a biological system at all the hierarchical levels fluid [5-6, 24-25,33]. The spatial position of the (ranging from local to regional and central) under biological molecules of all shapes and other biolog- external exposure, including weak exposure, can ical structures in an organism is maintained by the result in stress, depression, non-specific decrease in internal electrostatic and weak electromagnetic in- the immune response, and, consequently, predispoteractions typical of every living organism indivi- sition to various infectious, virus and other diseasdually as well as by control electromagnetic radia- es.

tion from the environment (of cosmic, circumtellu- Our studies show that the impact of strucrian, terrestrial and industrial nature). Terrestrial tured low-frequency or weak low-frequency lowforce fields, Schumann resonances, saturation with intensity radiation on physiological solution leads electromagnetic smog of technogenic origin, and to increased treatment effect from the preparation geopathogenic zones have a low intensity, but ex- that was preliminary affected by EMR [5, 33].

tended time of exposure. Affecting the main CNS We can suggest the ways to correct the rhythms, they can break the cerebral control im- impact of geomagnetic field (GMF) on human or pulses and thus change the immunological status of animal organism. If a low level of GMF activity is the organism in general as well as the spatial struc- undesirable, partial shielding of an the organism tures of the immune molecules shapes. must serve as the factor that compensate for the

Living structures, as in all the nature, are influence of the Earth's magnetic field. And, vice organized in fractals (a fractal is a fairly simple versa, if a high level of GMF activity is undesirastructure that consists of parts which are similar to ble, then it can be compensated by applying an the whole; it has become a single element of the EMF whose frequency is close to cyclotron. NatuMandelbrot family fractals [Benoit B. Mandelbrot. rally, these arguments require further testing.

The Fractal Geometry of Nature, 1977]). A change

When a human (animal) finds themselves in the components of any fractal at the micro-level in a new environment (microclimate) with lowin organized systems even under low and super-low intensity low-frequency electromagnetic fields, exposure (lower than kT- mean energy of the ther- their bodies experience new internal responses and mal motion of one molecule that equals $0.03 \mathrm{eV}$ ) is re-arrangements. In this regard, not only human reflected at the macroscopic level in the change of habitat on Earth should be paid attention to, but the shape and function of the whole. There are also extended space travel and exploration $[1,11]$. plenty of examples in nature. Water structures in The frequency rhythms that people on Earth are any living organism are the basis of the phase con- used to are based on Earth's main resonating fre-

Research Institute of Industrial and Marine Medicine of the Federal Office of Biomedical and Extreme, Russia, St. Petersburg, Yuri Gagarin Pr., 65 
quency, but on other planets it is different. For this reason, fundamental studies on human safety in space are very important and actual.

In conclusion we would like to point out that with the account for the ubiquity of artificial EMF sources both in the workplace environment and at home, lack of sufficient information about the nature of their negative biological impact, the World Health Organization (WHO) considers electromagnetic pollution to be one of the major issues that the humanity is currently facing and implements a large-scale program called "The International EMF Project"; Russia is one of the program's participants.

\section{References}

1. Dovgusha V.V., Tihonov M.N., Kudrin I.D. et al. Biologicheskoe dejstvie nizkointensivnyh jekologicheskih faktorov na organizm cheloveka [The biological effect of low-intensity of environmental factors on the human body]. Jekologija prom. proizvodstva. - 1999. - № 1. - P. 3-14.

2. Nikitina V.N., Lashko G.G., Kopytenko Ju.A. et al. Gigienicheskaja ocenka magnitnyh polej v jelektropoezdah i tehnologicheskih zonah metropolitena [Hygienic evaluation of the magnetic fields in electrical and technological areas of the subway]. Med. truda i prom. jekologija. - 2002. - № 3. - P. 1618.

3. Nikitina V.N., Fominich Ye.N., Myrova L.O. i dr. Gigienicheskie issledovanija jelektromagnitnoj obstanovki v jekranirovannyh sooruzhenijah [Hygienic researches of the electromagnetic environment in the screened constructions]. Morskoj med. zhurnal. - 1999. - № 5. - P. 17.

4. Dovgusha V.V., Dovgusha L.V. Jelektromagnitnye polja: Rol' i mehanizmy kontrolja nad soznaniem i zabolevaemost'ju [Electromagnetic fields: the role and mechanisms of mind control and morbidity]. Medicina jekstremal'nyh situacij. - № 2(24). - P. 49-59.

5. Dovgusha V.V., Lehtlaan-Tynisson N.P., Dovgusha L.V. Voda privychnaja i paradoksal'naja [Water familiar and paradoxical]. - SPb., 2007. -242 p.

6. Dovgusha V.V., Tikhonov M.N. Jelektromagnitnyj faktor - istochnik mnozhestva zabolevanij [Electromagnetic factor - the source of many diseases]. Medicina jekstremal'nyh situacij. - 1999. - № 1 . - P. 5-10.

7. Dovgusha V.V., Tihonov M.N., Dovgusha L.V. Volnovye vzaimodejstvija v biologii i medicine [Wave interactions in biology and medicine]. - SPb.: Poligraf-Atel'e, 2012. - 286 p.

8. Kopytenko Yu.A., Ptitsyna N.G. et al. Zagrjaznenie gorodskoj sredy ul'tranizkochastotnymi magnitnymi poljami ot jelektrotransporta // Pogoda i biosistemy [Urban pollution by the extra-lowfrequency magnetic fields from electric transport]. Mater. IV Mezhd. kongressa. - SPb., 11-14 October, 2006. - P. 85.

9. Zenchenko T.A. Analiz harakternyh osobennostej geofizicheskoj obstanovki v momenty aviacionnyh proisshestvij, proizoshedshih po raznym faktoram-prichinam [Analysis of the characteristics of geophysical conditions in date of the accident that occurred on various factors, reasons]. Slabye $i$ sverhslabye polja i izluchenija v biologii i medicine: Mater. IV Mezhd. kongressa. - SPb., 11-14 October, 2006. - P. 142.

10. Kalninsh K.K. Kataliticheskie svojstva vody: «zhivaja» i «mjortvaja» voda [The catalytic properties of water: "live" and "dead" water]. V kn.: Bioinformacionnyj resurs cheloveka: rezervy obrazovanija. Mater. nauch.- obrazovat. konf. - SPb., 2004. - P. 128-185.

11. Kontorov D.S., M.D. Kontorov, V.K. Spoka. Radioinformatika [Radio informatics]. - M., 1993. - 204 p.

12. Avakyan S.V., Voronin N.A., Borovkova O.K., V.V. Kovaljonok. Mezhplanetnye pilotiruemye poljoty v otsutstvii geomagnitnyh pul'sacij - psihofizicheskij aspekt [Interplanetary manned flights in the absence of geomagnetic pulsations - psychophysical aspect]. Slabye i sverhslabye polja i izluchenija $\mathrm{v}$ biologii i medicine: Mater. IV Mezhd. kongressa. - SPb., 11-14 October, 2006. - P. 157.

13. Minin B.A. SVCh i bezopasnost' cheloveka [Super-high frequency and human safety]. - M.: Sovetskoe radio, 1974. - $348 \mathrm{P}$.

14. Nikolis G., Prigozhin I. Poznanie slozhnogo [Complex cognition]. - M.: URSS, 2003. 15. O sostojanii okruzhajushhej sredy v Sankt-Peterburge i Leningradskoj oblasti v 1998 godu: Gosudarstven- 
nyj doklad v 2 t. [On the state of the environment in St. Petersburg and Leningrad region in 1998: State Report 2 tons.]. - SPb., 1999. - Vol. 1. -193 p.

16. Prigozhin I. Ot sushhestvujushhego k voznikajushhemu: vremja i slozhnost' v fizicheskih naukah [From Being to Becoming: Time and Complexity in the Physical Sciences]. - M.: URSS, 2002.

17. Prigozhin I.R. Postizhenie real'nosti [Reality comprehension]. Priroda. - 1998. - № 6. 18. Prigozhin I., Stengers I. Porjadok iz haosa [Order out of chaos]. - M.: URSS, 2003.

19. Reshenie Soveta bezopasnosti RF ot 20.02.1995 g. № 2-2 «Ob opasnosti jelektromagnitnogo zagrjaznenija okruzhajushhej sredy» [The decision of the Security Council of the Russian Federation of 20.02.1995, № 2-2 «The danger of the electromagnetic environment pollution"].

20. Rudakov M.L. Rossiyskie i evropejskie gigienicheskie normativy na parametry radioizluchenij dlja naselenija [Russian and European hygienic standards on the radio parameters for the population]. Standarty i kachestvo. - 1996. - № 4.

21. Ryabov Ju.G., Osipova A.Yu. Normirovanie jelektromagnitnoj bezopasnosti bytovyh priborov v Rossii i SShA [Rationing of electromagnetic safety of household appliances in Russia and the US]. Standarty i kachestvo. - 1996. - № 5.

22. Sanitarnye pravila i normy «Jelektromagnitnye izluchenija radiochastotnogo diapazona» (SanPiN 2.2.4/2.1.8.055-96) [Sanitary regulations and standards "Electromagnetic emissions of the radiofrequency range" (SanPiN 2.2.4 / 2.1.8.055-96)].

23. Serpov V.Ju. Bezopasnost' zhiznedejatel'nosti cheloveka v zonah geofizicheskih anomalij Evropejskoj Rossii [Vital activity security in the areas of geophysical anomalies in the European Russia]. $-\mathrm{SPb} ., 2005 .-128 \mathrm{p}$.

24. Slesarev V.I. Zagadki vody. Strukturno-informacionnoe svojstvo vody i javlenie «akvakommunikacii» [Mysteries of water. The structural and information property of water and the phenomenon of "aqua communications"]. Voda i jekologija (Problemy i reshenija). - 2004. - № 4 (21). - p. 49-83.

25. Slesarev V.I. Osnovy himii zhivogo [Principles of chemistry of vivo]. - SPb.: Himizdat, 2007. $-787 \mathrm{p}$.

26. Tikhonov M.N. Jelektromagnitnaja bezopasnost': vzgljad v budushhee. Problemy kompleksnoj zashhity organizma pol'zovatelej pri jekspluatacii komp'juternoj tehniki [Electromagnetic safety: looking into the future. Problems of complex organism protection of users in the operation of computer equipment]. - M.: VINITI RAN, 2005. - № 3. - p. 9-47.

27. Tikhonov M.N., Dovgusha V.V. Jelektromagnitnaja bezopasnost': postizhenie real'nosti [Electromagnetic safety: reality comprehension]. Jekologicheskie sistemy i pribory. - 1999. - № 4. - p. 4355 .

28. Tikhonov M.N., Dovgusha V.V., Kudrin I.D. Obshhestvo v uslovijah tehnogennogo pressinga jelektromagnitnyh izluchenij [Society in terms of technogenic electromagnetic radiation pressure]. Jekologija prom. proizvodstva. - 1998. - № 3-4. - p. 11-32.

29. Tikhonov M.N., Kudrin I.D. Chelovek i tehnika; «obshhenie» poljami [Human and Technology; "Communication" by fields]. Jenergija: jekonomika, tehnika, jekologija. - 1997. - №11. - P. 26-27.

30. Hagen G. Sinergetika: ierarhii neustojchivostej v samoorganizujushhihsja sistemah i ustrojstvah: Per. s angl. [Synergetics: Instability Hierarchies in self-organizing systems and devices: Trans. from English.]. - M.: Mir, 1985. - 320 p.

31. Chizhevskij A.L. Kosmicheskij pul's zhizni [Cosmic Pulse of Life]. - M.: Mysl', 1995. - 768 s. 32. Crasson M. et al. Absence of daytime $50 \mathrm{~Hz}, 100 \mu \mathrm{Trms}$ magnetic field or bright light exposure effect on human perform. P... ance and psychophysiological parameters // Bioelectromagnetics. - 2005. Vol. 26, № 3. - P. 222-233.

33. Fuller M., Dobson J. On the significance of the constant of magnetic field sensitivity in animals // Bioelectromagnetics. - 2005. - Vol. 26, № 3. - P. 234-237.

34. Gordon C., Berk M. The effect of geomagnetic storms on suicide//Safr Psychiatry Rev. -2003. - Vol. 6. - P. 24-27.

35. Prigogine I., Nicolis G. Self - Orgazation in Non-Equilibrium System: From Dissipative Structures to Order Through Fluctuations. - New York: J. Wiley\&Sons, 1977. 